\title{
Physiology of Epithelial Chloride and Fluid Secretion
}

\author{
Raymond A. Frizzell ${ }^{1}$ and John W. Hanrahan ${ }^{2}$ \\ ${ }^{1}$ Department of Cell Biology and Physiology, University of Pittsburgh School of Medicine, Pittsburgh, \\ Pennsylvania 15261 \\ ${ }^{2}$ Department of Physiology, McGill University, Montreal, Quebec H3G 1Y6, Canada \\ Correspondence: frizzell@pitt.edu
}

Epithelial salt and water secretion serves a variety of functions in different organ systems, such as the airways, intestines, pancreas, and salivary glands. In cystic fibrosis (CF), the volume and/or composition of secreted luminal fluids are compromised owing to mutations in the gene encoding CFTR, the apical membrane anion channel that is responsible for salt secretion in response to CAMP/PKA stimulation. This article examines CFTR and related cellular transport processes that underlie epithelial anion and fluid secretion, their regulation, and how these processes are altered in CF disease to account for organ-specific secretory phenotypes.

$\mathrm{T}^{\mathrm{h}}$ he formation and maintenance of the fluid compartment at the apical (luminal) surface of epithelia are critical for the normal functions of numerous organ systems. Examples include the airway surface liquid (ASL) layer of the conducting airways, which is vital to mucociliary clearance, generation of the liquid vehicle for secretion of pancreatic digestive enzymes and their delivery to the intestinal lumen, and in the intestine, maintenance of an appropriate level of luminal fluidity for digestion. In terms of volume, intestinal secretion is the greatest, estimated at $\sim 8 \mathrm{~L} / \mathrm{d}$ (Barrett and Keely 2000). In cystic fibrosis $(\mathrm{CF})$, the formation of luminal fluid, and often its composition, is impaired, and these deficits underlie the complex manifestations of organ pathophysiology that characterize this disease.
At the basis of these defects is CFTR, the apical membrane anion channel with the capacity for regulated secretion of $\mathrm{Cl}, \mathrm{HCO}_{3}$, and smaller amounts of other anions. Chloride secretion establishes an electrical driving force (lumen-negative) for trans-epithelial sodium secretion via the paracellular pathways, and together, their movements into the luminal compartment generate the osmotic driving force for water flow that yields an isotonic secretory product. The net result of a missing or defective CFTR channel is therefore disruption of secreted fluid volume and composition, and in the systems mentioned, defects in airway clearance of mucins and bacteria, pancreatic insufficiency, and intestinal obstruction (for organ system details, see below and "Role of CFTR in the Secretion of Other Anions").

Editors: John R. Riordan, Richard C. Boucher, and Paul M. Quinton

Additional Perspectives on Cystic Fibrosis available at www.perspectivesinmedicine.org

Copyright (C) 2012 Cold Spring Harbor Laboratory Press; all rights reserved; doi: 10.1101/cshperspect.a009563

Cite this article as Cold Spring Harb Perspect Med 2012;2:a009563 


\section{R.A. Frizzell and J.W. Hanrahan}
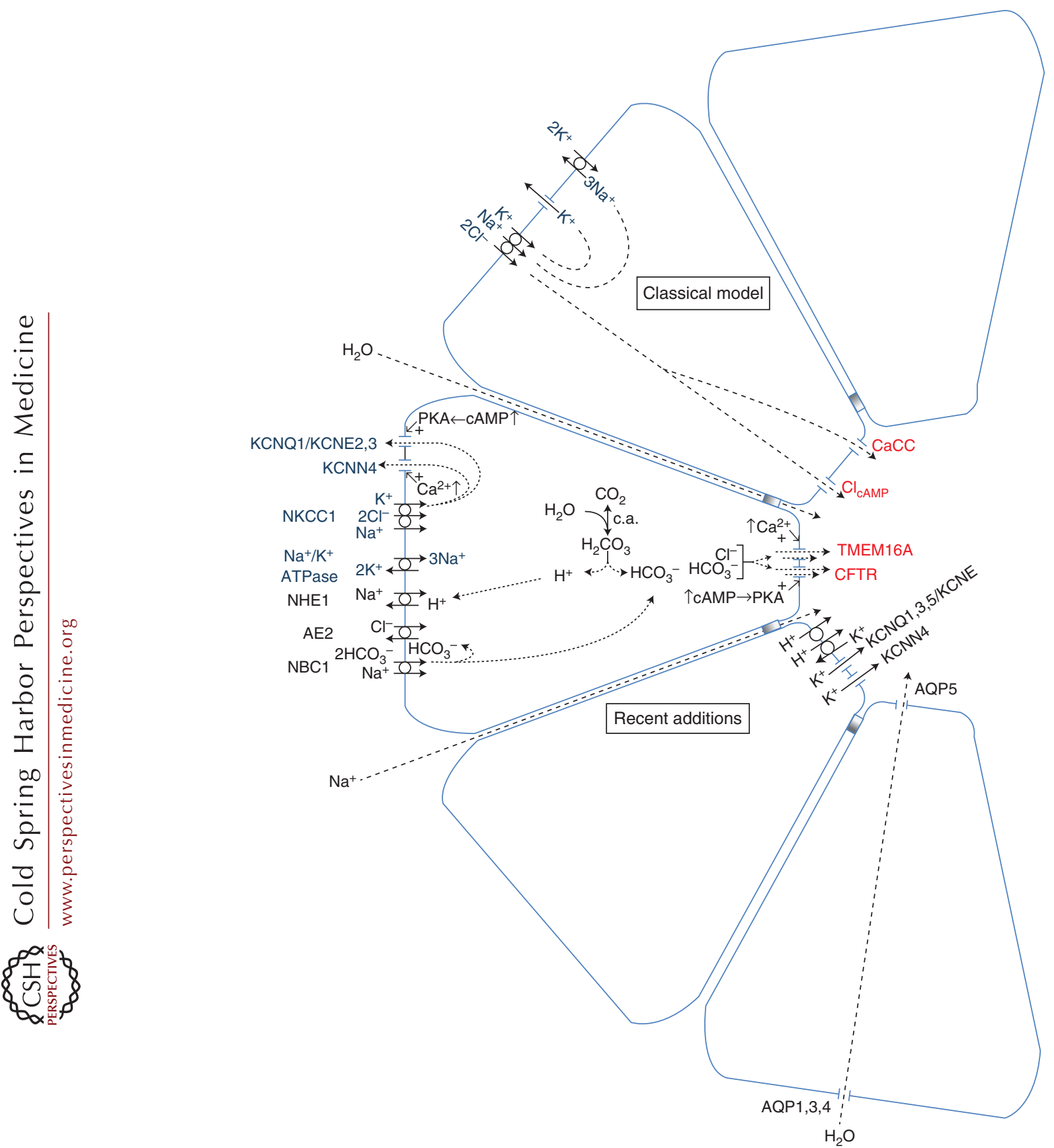

Figure 1. Schematic of the transport pathways in secretory epithelia. As shown in the "Classical model," $\mathrm{Cl}^{-}$ entry across the basolateral membrane is driven primarily via $\mathrm{Na}^{+}$cotransport. Apical $\mathrm{Cl}^{-}$efflux is mediated by cAMP- and $\mathrm{Ca}^{2+}$-activated anion conductances. The scheme labeled "Recent additions" identifies the numerous transporters and channels proposed to mediate ion and fluid secretion in various epithelia. Accordingly, basolateral $\mathrm{Cl}^{-}$loading may occur via both $\mathrm{NKCC} 1$ and $\mathrm{AE} 2 . \mathrm{Cl}^{-}$and $\mathrm{HCO}_{3}^{-}$exit involves apical CFTR, TMEM16A, and probably other $\mathrm{Cl}^{-}$channels/transporters, such as members of the SLC26A family (data not shown). (Legend continues on facing page.) 
This article examines the basic, cellular events that underlie epithelial anion and fluid secretion, including the component transport processes and their regulation. Newer findings linking other transport and channel functions to the activity or trafficking of CFTR will determine the tissue-specific secretory phenotype and how these physiological properties are altered in CF disease.

\section{BASIC TRANSPORT COMPONENTS OF ANION SECRETION}

Marine biology has made significant contributions to the study of epithelial ion transport. Key among them is a series of experiments performed in the late 1930s by the Danish physiologist and Nobel Laureate August Krogh, using the skin and gills of freshwater animals. This work led Krogh to the conclusion that metabolic energy was required to maintain the ionic gradients between the organism and its external environment that permit specialization, and he and his collaborators introduced the use of radioisotopes to define the underlying transport events. His student Hans Ussing combined isotopic ion fluxes and biophysical approaches to form our basic knowledge of epithelial polarity, active and passive transport, the paracellular pathway, and the origins of epithelial "bioelectric potentials” (Larsen 2002). Once Jens Christian Skou identified the Na,K-ATPase and linked it to cation transport (Skou 1998), the ensuing decades firmly established the central role of this active transport process as the energy source for the secondary active transport of many nutrients and ions. Ultimately, these principles were applied in the context of active anion secretion, leading to the classical cellular model, its basic principles being applicable to many secretory epithelia (Fig. 1).

Active $\mathrm{Cl}$ secretion and second-messenger pathways converged when the dramatic fluid secretion evoked by intestinal infection with Vibrio cholerae was linked with an active $\mathrm{Cl}$ secretory process, modeled in studies of rabbit intestine mounted in Ussing chambers and stimulated by cAMP or agents that increase its cellular levels (Kimberg et al. 1971). The basic transport principles were enumerated (Frizzell et al. 1979), and over the next decade, their molecular identities were established (see Fig. 1). A rise in cellular cAMP, which can be elicited by numerous primary agonists, evokes anion secretion by stimulating three basic transport processes: the apical anion channel CFTR, basolateral $\mathrm{K}$ channels of at least two types, and the basolateral $\mathrm{Na}$-coupled $\mathrm{Cl}$ entry process, $\mathrm{NKCC1}$ $(\mathrm{Na} / \mathrm{K} / 2 \mathrm{Cl}$ cotransporter 1$)$.

\section{Transport at the Apical Membrane}

\section{Apical CFTR}

This section reviews the many facets of CFTR structure, function, and regulation. As noted, CFTR is in the large family of ATP-binding cassette $(\mathrm{ABC})$ proteins, whose members are composed of two membrane-spanning domains (MSD1 and 2) and two nucleotide-binding domains (NBD1 and 2) arranged in series in the primary structure (Riordan et al. 1989). Uniquely, CFTR contains a central R (regulatory) region, which contains nine strong consensus sequences for phosphorylation by protein kinase A (PKA) and additional sites of phosphorylation by other kinases (e.g., PKC, AMPK). Another significant

Figure 1. (Continued) NBC1-mediated $\mathrm{HCO}_{3}^{-}$entry during cAMP stimulation maintains intracellular $\mathrm{pH}$ and generates electrogenic trans-epithelial $\mathrm{HCO}_{3}^{-}$secretion. NHE1 maintains intracellular $\mathrm{pH}$ during stimulation by $\mathrm{Ca}^{2+}$ secretagogues when cells are hyperpolarized and net $\mathrm{Cl}^{-}$secretion is favored. There is evidence for apical $\mathrm{H}^{+}$secretion mediated by vacuolar proton pumps, $\mathrm{H}^{+} / \mathrm{K}^{+}$-ATPase, and also apical $\mathrm{K}$ channels, which contribute to apical hyperpolarization and thus enhance the driving force for anion secretion. Most trans-epithelial $\mathrm{Na}^{+}$ flux occurs passively through the paracellular pathway driven by the lumen-negative voltage arising from electrogenic anion secretion. In both schemes, regulated apical anion conductance is rate-limiting at low/ medium levels of anion secretion, but basolateral $\mathrm{K}$ conductance becomes increasingly limiting at higher secretory rates, explaining the additive nature of secretagogues that operate via different second-messenger pathways. 
PKA phosphorylation site in the regulatory insertion of NBD1 is discussed below. As a primary event in secretion, protein kinase A (PKA) phosphorylates the $\mathrm{R}$ region, which then enables channel gating (opening and closing). Gating and $\mathrm{Cl}$ secretion are elicited by the binding and hydrolysis of ATP at the NBDs (see below for details). As discussed below, CFTR is not the sole pathway for apical $\mathrm{Cl}$ exit, but it is the predominant pathway for secretion in response to agonists that act via cAMP/PKA-dependent phosphorylation. In addition, CFTR exhibits a significant conductance to bicarbonate, which is reviewed below in "Anion Secretion by Alternate Apical Pathways.”

\section{Requirements at the Basolateral Membrane}

\section{Na/K Pump}

The basolateral membrane $\mathrm{Na} / \mathrm{K}$ pump (ATPase) is the primary, energy-using process that establishes the electrochemical gradients for secondary active anion secretion. It transports three $\mathrm{Na}$ ions out of the cell in exchange for two $\mathrm{K}$ ions pumped into the cell, with the energetic revenue derived from the conversion of one ATP to ADP (Skou 1998). Because the pump is itself electrogenic, it contributes to the inside-negative basolateral membrane potential, the magnitude of its contribution dependent on the parallel electrical resistance. The primary determinant of the membrane voltage, however, is the leakage of potassium out of the cell via a collection of basolateral (and apical in some cell types) $\mathrm{K}$ channels, which are primarily responsible for determining the membrane potential (see further discussion below). In most cells, the pump is a major consumer of metabolic energy, but in epithelia, it may account for twothirds of the cell's energy expenditure. Airway cells in cystic fibrosis are reported to consume oxygen at a rate two to three times that observed in non-CF tissues, and they express more binding sites for ouabain (Stutts et al. 1986), findings that reflect the higher rate of pump expression and turnover due to enhanced $\mathrm{Na}$ absorption across CF airway epithelia ("Anion Secretion by Alternate Apical Pathways"). Nevertheless, recent findings in an animal model of CF have challenged this view (Chen et al. 2010).

\section{Basolateral K Channels}

An increase in basolateral $\mathrm{K}$ conductance is necessary to recycle $\mathrm{K}$ brought into the cell by the $\mathrm{Na} / \mathrm{K}$ pump and to maintain an electrical driving force for anion exit across the apical membrane. Owing to the large increase in $\mathrm{Cl}$ conductance associated with the activation of CFTR, or other apical anion channels, the apical membrane voltage approaches the $\mathrm{Cl}$ equilibrium potential. But in response to second-messenger pathways, basolateral $\mathrm{K}$ channels are also activated, to coordinate membrane repolarization with the activation of apical $\mathrm{Cl}$ conductance and permit the membrane potentials to repolarize toward the $\mathrm{K}$ equilibrium potential, establishing the electrical driving force for $\mathrm{Cl}$ exit across the apical membrane.

Activation of apical CFTR-mediated anion secretion by cAMP/PKA is paralleled by PKA phosphorylation and activation of a basolateral membrane K channel, KCNQ1 (aka LQT1). The requirement for basolateral $\mathrm{K}$ conductance activation is evidenced by the impact of blocking these pathways with the generalized $\mathrm{K}$ channel blocker barium. Barium inhibits anion secretion by depolarizing the membrane potentials toward electrochemical equilibrium for $\mathrm{Cl}$ at the apical membrane and thereby blocking $\mathrm{Cl}$ secretion (Smith and Frizzell 1984; Welsh and McCann 1985). In many epithelia, the basolateral $\mathrm{K}$ conductance is composed of at least two $\mathrm{K}$ channel types. KCNQ1 is activated primarily during CAMP/PKA-induced secretion, its single channel conductance is low $(\sim 3 \mathrm{pS})$, and it is inhibited selectively by the chromanol 293B and by HMR-1556 (Gerlach et al. 2001; Kunzelmann et al. 2001). The contribution of KCNQ1 to the total $\mathrm{K}$ conductance varies with secretory agonist type and is tissue/cell-type dependent (Liao et al. 2005).

On the other hand, secretion stimulated by a cellular Ca rise primarily activates the intermediate conductance, Ca-activated channel KCNN4 (Devor and Frizzell 1998; Kunzelmann et al. 2001). Nevertheless, it is difficult to generalize, 
Physiology of Chloride and Fluid Secretion

because multiple channel isoforms and $\beta$ subunits may be expressed in different cell types, and these can assemble as homo- or heterodimers with somewhat different properties. Two-pore K channels have also been found in intestinal secretory cells. These channels may also target to the apical membrane to mediate $\mathrm{K}$ secretion in some epithelia (e.g., airway) (Heitzmann and Warth 2008). It is interesting that a splice variant of the calcium-activated, intermediate conductance $\mathrm{K}$ channel KCNN4, which is usually considered basolateral, has also been shown at the apical membrane in colon, where it mediates $\mathrm{K}$ secretion and contributes to the driving force for $\mathrm{Cl}^{-}$secretion (Joiner et al. 2003; Nanda Kumar et al. 2010). This may be a more general phenomenon than previously thought, because most epithelial secretions have elevated $[\mathrm{K}]$ compared with plasma (typically twofold to fourfold) and may also involve several members of the KCNQ channel family (Namkung et al. 2009).

\section{Basolateral NKCC1}

Chloride entry across the basolateral membranes of secretory epithelia is mediated primarily by this $\mathrm{Na} / \mathrm{K} / 2 \mathrm{Cl}$ cotransporter isoform. The driving force for cellular $\mathrm{Cl}$ entry and accumulation is supplied primarily by the inward chemical gradient of $\mathrm{Na}$ established by the pump; the basolateral membrane potential does not influence this electrically neutral process. Ultimately, the rate of basolateral $\mathrm{Cl}$ entry via $\mathrm{NKCC} 1$ determines the overall rate of $\mathrm{Cl}$ secretion, which requires coordination of transport events at the limiting membranes to maintain the steady state. The timing of NKCC1 activation generally follows that of CFTR and the $\mathrm{K}$ channels, resulting in some loss of cellular $\mathrm{Cl}$ and $\mathrm{K}$ and a resulting decrease in cell volume.

This is a key feature of NKCC1 regulation, because reduced cell $\mathrm{Cl}$ concentration and volume trigger the activation of the WNK kinase (McCormick and Ellison 2011), which phosphorylates the SPAK (surface presentation of antigens protein) and OSR1 (oxidative stress responsive 1) kinases, which, in turn, phosphorylate the cotransporter amino terminus to activate its turnover (Mercier-Zuber and
O'Shaughnessy 2011). NKCC1 was the first recognized binding partner of SPAK and OSR1. Phosphorylation of NKCC1 at three threonines (lying within amino acids 203-212) gives rise to the stimulation of NKCC1 turnover, and mutations at these sites reduce its response to low $\mathrm{Cl}$ or hyperosmotic-induced cell shrinkage (Richardson et al. 2008). The role of SPAK in this signaling cascade has been confirmed in knockout or knockin mice in which the expression of SPAK-bearing mutations at critical threonine residues blocks the ability of WNKs to activate NKCC1. It was also of interest that the expression level of NKCC1 was reduced in mice expressing mutant SPAK, suggesting that this kinase controls both the activity and the expression level of NKCC1. A current critical question in the field is the mechanism by which WNKs are activated by low $\mathrm{Cl}$ and cell shrinkage. An interaction with the cytoskeleton or cell adhesion molecules could perhaps serve as a transducer of its activity.

\section{Basolateral Anion Exchange (AE)}

Although early studies pointed to a mechanism in which secretion involved $\mathrm{Na}^{+}$-coupled $\mathrm{Cl}^{-}$ entry at the basolateral membrane, a large fraction of the $\mathrm{Cl}$ and fluid secretion by salivary glands and other epithelia was found to be insensitive to the NKCC1 inhibitor bumetanide but was sensitive to inhibitors of carbonic anhydrase (acetazolamide and ethoxolamide) and to amiloride and dimethyl amiloride. In salivary glands (see Fig. 1), this component of secretion was attributed to the parallel operation of basolateral $\mathrm{Cl} / \mathrm{HCO}_{3}$ and $\mathrm{Na} / \mathrm{H}$ exchangers (Novak and Young 1986; Pirani et al. 1987). Carbonic anhydrase was proposed to catalyze cellular $\mathrm{HCO}_{3}$ synthesis, and because $\mathrm{CO}_{2}$ hydration would generate carbonic acid and acidload the cell, $\mathrm{H}$ extrusion, for example, by amiloride-sensitive $\mathrm{Na} / \mathrm{H}$ exchange, was proposed to maintain intracellular $\mathrm{pH}$ and thus transepithelial $\mathrm{Cl}$ secretion. Basolateral $\mathrm{Cl}$ uptake by anion exchangers has been suggested in various epithelia including equine trachea (Tessier et al. 1990) and the Calu-3 cell line (Cuthbert et al. 2003; Krouse et al. 2004; Shan et al. 2011). 
R.A. Frizzell and J.W. Hanrahan

The molecular basis of the basolateral $\mathrm{Cl}^{-}$ entry process may be the $\mathrm{Na}$-independent anion exchanger AE2 (SLC4A2), particularly in acidsecreting cells that must cope with an intracellular alkaline load. AE2 is expressed at high levels in parietal cells of the gastric epithelium, and null mice display a dramatic gastric epithelial phenotype with abnormal canaliculae and reduced $\mathrm{HCl}$ secretion (Gawenis et al. 2004). Other Cl-secreting epithelia are also affected, notably the proximal colon (Gawenis et al. 2010); the role of AE2 has been difficult to establish in most tissues because it is electrically silent, there are no specific inhibitors available, and AE2-null mice die soon after birth. AE2 is expressed in the basolateral membrane of Calu-3 cells (Loffing et al. 2000), and recent studies of a stable, AE2-deficient Calu-3 cell line under open-circuit conditions revealed that AE2 mediates most basolateral anion exchange (Huang et al. 2011) and accounts for up to $70 \%$ of the net $\mathrm{Cl}^{-}$flux during cAMPstimulated fluid secretion (Shan et al. 2011).

\section{Essential Role of the Paracellular Pathway and Membrane Coupling}

Secretory epithelia are polarized sheets of cells that require distinct sets of apical and basolateral membrane transporters to perform vectorial transport. Nevertheless, the apical and basolateral membranes are functionally coupled by the paracellular pathway, and this shunt for ions and fluid is essential in secretory epithelia, most of which are of moderate leakiness (intermediate conductance). Early evidence for its involvement in salivary gland secretion was provided by Lundberg (1957), although definitive demonstration of the paracellular shunt in epithelia did not come until much later (Frömter and Diamond 1972). The paracellular shunt facilitates secretion by causing hyperpolarization of the apical membrane away from the $\mathrm{Cl}^{-}$equilibrium potential $\left(\mathrm{E}_{\mathrm{Cl}}\right)$ during stimulation of apical $\mathrm{Cl}^{-}$channels. According to the simplest equivalent circuit model for epithelia (Fig. 2):

$$
V_{\mathrm{a}}=\frac{E_{\mathrm{a}}\left(R_{\mathrm{b}}+R_{\mathrm{s}}\right)+E_{\mathrm{b}} R_{\mathrm{a}}}{R_{\mathrm{a}}+R_{\mathrm{b}}+R_{\mathrm{s}}}
$$

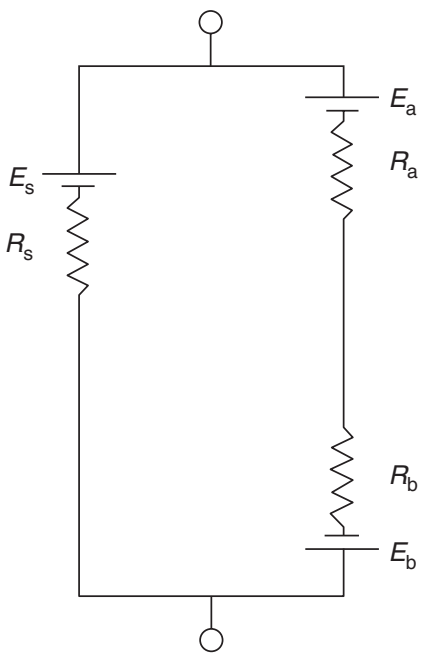

Figure 2. Simplest equivalent circuit that can describe ionic currents across epithelia. Net electromotive forces (EMFs) that result from ion concentration gradients across the apical membrane $\left(E_{\mathrm{a}}\right)$, basolateral membrane $\left(E_{\mathrm{b}}\right)$, and paracellular "shunt" pathway $\left(E_{\mathrm{s}}\right)$ are shown as batteries. Membrane conductances that mediate electrogenic (non-neutral) ion flows driven by those EMFs are depicted as resistors.

In Equation $1, V_{\mathrm{a}}$ is the apical membrane potential; $R_{\mathrm{a}}, R_{\mathrm{b}}$, and $R_{\mathrm{s}}$ are the electrical resistances of the apical, basolateral, and shunt ( paracellular) pathways, respectively; and $E_{\mathrm{a}}$ and $E_{\mathrm{b}}$ are the electromotive forces at the apical and basolateral membranes. The activation of large numbers of apical CaCC and CFTR $\mathrm{Cl}^{-}$channels by secretagogues dramatically reduces apical membrane resistance. As $R_{\mathrm{a}}$ (and thus $E_{\mathrm{b}} R_{\mathrm{a}}$ ) falls, the ratio $\left(R_{\mathrm{b}}+R_{\mathrm{s}}\right) /\left(R_{\mathrm{a}}+R_{\mathrm{b}}+R_{\mathrm{s}}\right)$ approaches 1 if $R_{\mathrm{s}}$ is high, and the apical membrane potential $V_{\mathrm{a}}$ approximates $E_{\mathrm{a}}$, as in tight epithelia. Essentially, the high $\mathrm{Cl}^{-}$conductance during stimulated secretion would clamp $V_{\mathrm{a}}$ at $E_{\mathrm{Cl}}\left(=E_{\mathrm{a}}\right)$ if $R_{\mathrm{s}}$ were high, thereby eliminating the favorable driving force for $\mathrm{Cl}$ exit and secretion. However, when there is a large paracellular shunt and $R_{\mathrm{s}}$ is low compared with $R_{\mathrm{b}}$, as in moderately leaky secretory epithelia, then $V_{\mathrm{a}}$ is influenced by the loop current, which flows through basolateral $\mathrm{K}^{+}$ channels and the shunt pathway, driven by $E_{\mathrm{K}}$ at the basolateral membrane. When this current flows through the apical membrane $\left(E_{\mathrm{b}} R_{\mathrm{a}}\right)$, it causes hyperpolarization and promotes $\mathrm{Cl}^{-}$ 
secretion through an increase in net driving force $\left(V_{\mathrm{a}}-E_{\mathrm{Cl}}\right.$ ) (Welsh et al. 1983; Willumsen et al. 1989). It is also obvious from Equation 1 that secretion is inefficient when $\mathrm{Ca}^{2+}$ and cAMP stimulate only apical channels, because the impact of the basolateral membrane and its driving force diminishes as apical channels become activated (i.e., when $R_{\mathrm{a}}$ and therefore $E_{\mathrm{b}} R_{\mathrm{a}}$ decrease). Therefore, it is not surprising that in most epithelia, activation of basolateral $\mathrm{Ca}-$ and/or cAMP-activated K channels (e.g., KCNN4 and KCNQ1/KCNE) by secretagogues is coordinated with that of apical $\mathrm{Cl}$ channels. In summary, secretory epithelia need to be somewhat leaky because the paracellular shunt pathway functionally couples the apical and basolateral membranes and maintains the apical driving force for $\mathrm{Cl}$ secretion. Indeed, an increase in the shunt can lead to excessive secretion as in the intestine, where a marked increase in paracellular permeability leads to secretion during T-cell-mediated diarrhea (Clayburgh et al. 2005).

\section{ANION SECRETION BY ALTERNATE APICAL PATHWAYS}

\section{Calcium-Activated Chloride Channels}

Calcium-activated $\mathrm{Cl}$ conductance $(\mathrm{CaCC})$ is a major pathway for $\mathrm{Cl}$ transport in nearly all cells, but it was first characterized in detail in a secretory epithelium (Marty et al. 1984). It is activated when intracellular $\mathrm{Ca}$ is elevated to micromolar concentrations, and also by membrane depolarization at low cell [Ca], although it becomes almost voltage independent at high [Ca]. The single channel conductance estimated by noise analysis is $1-2 \mathrm{pS}$, and the channels have a "weak field strength" selectivity sequence (Eisenman 1962; Wright and Diamond 1977; Evans and Marty 1986). Ca-activated $\mathrm{Cl}^{-}$conductance was proposed to be the main apical $\mathrm{Cl}$ pathway during muscarinic stimulation of lacrimal glands (Marty et al. 1984), but this pathway has been identified in virtually all gland epithelial cells, where it is stimulated by a wide range of Ca-mobilizing agonists.

The search for the channel protein that mediates $\mathrm{CaCC}$ has uncovered many interesting candidates during the past 25 years. One of the early possibilities, human CLCA1, now appears to be a secreted protein rather than a $\mathrm{Cl}$ channel (Gibson et al. 2005), although it is nevertheless reported to modulate the conductance of endogenous Ca-activated $\mathrm{Cl}^{-}$channels (Hamann et al. 2009). The putative high-conductance Caactivated $\mathrm{Cl}$ channel tweety (hTTYH3) remains a candidate channel, although little is known regarding its physiological role (Suzuki and Mizuno 2004). A member of the ClC family, $\mathrm{ClC} 3$, has also been proposed to mediate $\mathrm{CaCC}$ but is predominantly intracellular and may function as a $\mathrm{Cl} / \mathrm{H}$ exchanger. Human bestrophin 1 , which is mutated in a juvenile form of macular degeneration called Best vitelliform macular dystrophy ("Best disease"), forms $\mathrm{Cl}$ and $\mathrm{HCO}_{3}$-permeable channels in the plasma membrane, but they have a biophysical signature that is distinct from that of epithelial $\mathrm{CaCC}$ (Hartzell et al. 2008).

The most compelling candidate to mediate CaCC is TMEM16A, which was identified almost simultaneously by three independent groups using different approaches: expression cloning (Schroeder et al. 2008), bioinformatics (Yang et al. 2008), and differential gene expression (Caputo et al. 2008). The channel has also been named "Anoctamin-1" because it is predicted to have eight transmembrane segments. The anion selectivity and pharmacology of TMEM16A are consistent with those of $\mathrm{CaCC}$, and it is expressed in exocrine glands and, indeed, all epithelia that exhibit CaCC currents, including airways and renal tubules. Silencing its expression in cell cultures and tissues reduces CaCC activity (Yang et al. 2008), and knockout mice are deficient in CaCC activity in salivary glands and other tissues (Ousingsawat et al. 2009; Ferrera et al. 2010; Romanenko et al. 2010). Nevertheless, other channels may contribute to $\mathrm{CaCC}$ in airway and intestinal epithelia because basal secretion and up to $40 \%$ of the UTP-stimulated CaCC activity persists in TMEM16A knockout mice (Rock et al. 2009), and only a transiently activated $\mathrm{CaCC}$ current appears sensitive to RNAi knockdown and pharmacological inhibitors of TMEM16A (Namkung et al. 2011). Other CaCC channels might 
be expected under control conditions, because TMEM16A is normally expressed at low levels and strongly induced by proinflammatory cytokines (Caputo et al. 2008). This also raises the exciting prospect that more CaCCs remain to be discovered.

\section{SLC26A Transporters and Channels}

The contribution of the SLC26A family of anion transporters to $\mathrm{HCO}_{3}$ secretion in several epithelia was established with the recognition that congenital chloride-losing diarrhea (CLD) was linked to mutations in the $\mathrm{Cl} / \mathrm{HCO}_{3}$ exchanger encoded by SLC26A3 (Hoglund et al. 1996). CLD patients exhibit diarrhea characterized by high $\mathrm{Cl}$ concentrations and metabolic alkalosis suggestive of defective $\mathrm{Cl} / \mathrm{HCO}_{3}$ exchange, and mice lacking Scl26a3 recapitulate this phenotype (Schweinfest et al. 2006). Some CLD-causing mutations lead to misfolding of the transporter and disrupt its apical trafficking (Dorwart et al. 2008a). Ten members of this family have been separated into three groups, based on their transport properties (Dorwart et al. 2008b). Group 1 contains the sulfate transporters $\mathrm{A} 1$ and $\mathrm{A} 2$; Group 2 the $\mathrm{Cl} / \mathrm{HCO}_{3}$ exchangers $\mathrm{A} 3, \mathrm{~A} 4$, and A6; and Group 3, represented by A7 and A9, exhibits anion channel behavior. SLC26A5 is expressed in outer hair cells of the cochlea, and A8 is present in male germ cells. Many SCL26 transporter members have been associated with human diseases (Mount and Romero 2004).

In regard to epithelial $\mathrm{HCO}_{3}$ secretion, differences in anion transport stoichiometry among Group 2 family members have been proposed to account for the ability of the pancreatic duct epithelium to generate a final $\mathrm{NaHCO}_{3}$ concentration that is isotonic to the plasma. Specifically, A6, with a stoichiometry of $1 \mathrm{Cl}$ / $2 \mathrm{HCO}_{3}$, appears to be required for the generation of high luminal $\mathrm{HCO}_{3}$ concentrations as $\mathrm{Cl}$ concentrations fall along the pancreatic duct (Ko et al. 2004; Steward et al. 2005). Mice lacking Slc26a6 show impaired pancreatic duct and intestinal $\mathrm{Cl} / \mathrm{HCO} 3$ exchange and impaired pancreatic fluid secretion (Wang et al. 2006; Ishiguro et al. 2007; Seidler et al. 2008). SLC26A6 may be responsible for generating other $\mathrm{HCO}_{3}$-rich se- cretory products, as observed in the salivary gland (Shcheynikov et al. 2008). The ability of intestinal A6 to transport oxalate is likely involved in protecting against renal stone formation (Aronson 2010).

The Group 3 anion channels include SLC26A7, which is reported to be relatively selective for $\mathrm{Cl}$ and to conduct $\mathrm{Cl}$ in a $\mathrm{pH}$-dependent manner (Kim et al. 2005). However, other transport modes involving coupled $\mathrm{HCO}_{3}$ exchange have also been proposed (Petrovic et al. 2003, 2004; Kim et al. 2005). A7 has been found in the basolateral membranes of gastric parietal cells, where it may contribute to $\mathrm{Cl}$ entry from the interstitium; it is found in several renal nephron segments. A7 may be located at the apical or basolateral membranes in various epithelia, and the factors that determine its targeting are not known. SLC26A9 is reported to lie at the apical membranes of ciliated airway epithelial cells and alveolar cells, and it is present also in the gastric mucosa (Xu et al. 2008). In primary cultures of human bronchial epithelium (HBE), SLC26A9 appears to account for the basal secretory current that remains after amiloride inhibition of $\mathrm{Na}$ absorption, and it contributes also to anion secretion in response to cAMP/PKA-mediated stimulation (Bertrand et al. 2009). Interestingly, A9 currents were inhibited by the CFTR blocker GlyH-101, but they showed less voltage-dependent block than CFTR, allowing these current components to be distinguished. As observed for other SLC26 transporters, the cAMP/PKA-stimulated currents observed during coexpression of A9 with CFTR exceeded those observed for either channel alone, indicative of a mutual stimulatory interaction (see below). Interestingly, A9 currents were absent from HBE or HEK cells expressing $\Delta$ F508 CFTR, which may be consistent with the strong interaction between A9 and CFTR found in coimmunoprecipitation experiments.

Of great interest for the CF field is the regulation of SLC26A-mediated transport, because several members of this family have been linked functionally to the activation of CFTR (Ko et al. 2004; Dorwart et al. 2008b). As with CFTR, several SLC26A family members possess PDZ- 
domain-interacting motifs at their carboxyl termini. This motif allows them to associate with CFTR via scaffolding proteins such as NHERF 1 and 2 and CAP70 in macromolecular complexes that are likely to include cytoskeleton-interacting proteins (e.g., ezrin) (Short et al. 1998) and links to regulatory proteins such as PKA (Sun et al. 2000a,b). The intriguing studies of Ko et al. (2004) suggest that mutual stimulatory interactions between SLC26A3, A6, and CFTR involve regulated association between subdomains of these proteins, the $\mathrm{R}$ region of CFTR, and the carboxy-terminal STAS domain of A6, allowing their stimulatory reciprocity to be enhanced by PKA phosphorylation of the $\mathrm{R}$ region of CFTR (Ko et al. 2004). The interaction between STAS and the $\mathrm{R}$ region could influence CFTR gating by altering the dynamic interaction of the $\mathrm{R}$ region with NBD subdomains, identified by NMR (Baker et al. 2007; Kanelis et al. 2010). Thus, interactions between CFTR and different SLC26 transporters in different epithelia might explain how PKA-induced stimulation of CFTR can give rise to tissue-specific secretory products, as well as the diverse transport phenotypes observed when CFTR is absent or impaired in CF.

\section{ROLE OF CFTR IN THE SECRETION OF OTHER ANIONS}

Another important aspect of the physiology of anion secretion mediated by CFTR concerns the lack of strict anion selectivity that CFTR and other anion channels display, contrasting with their highly selective cation channel counterparts. In recent years, it has been recognized that two physiologically significant anions also permeate the CFTR channel-glutathione and thiocyanate.

\section{Glutathione}

CFTR is permeable to glutathione, and other ABC transporters have been shown also to transport glutathione (GSH), a major antioxidant that is present in cells at millimolar concentrations (Linsdell et al. 1997). GSH was 55\% lower in airway surface liquid of CFTR-deficient cultures. The presence of airway bacteria has been shown to generate increases in airway surface liquid GSH, and in CFTR knockout mice, failure to secrete GSH has been linked to airway inflammation and oxidative stress (Day et al. 2004). Accordingly, in CF, deficient glutathione transport via CFTR has the potential to influence the redox state of both the luminal and cellular compartments of epithelial cells and lead to oxidative stress. These disturbances to the redox balance can evoke inflammatory signaling pathways and could be linked to apoptosis (Rahman and MacNee 1998; Haddad 2002; Rottner et al. 2009). Thus, altered glutathione levels can contribute to NF-kB activation and to the inflammation evoked by bacterial colonization.

\section{Thiocyanate}

Airway epithelia secrete thiocyanate anion (SCN) via CFTR, as a precursor for the production of the potent antibacterial compound hypothiocyanate anion (OSCN) (Conner et al. 2007). Early studies of CFTR's anion selectivity showed that SCN permeability exceeded that to $\mathrm{Cl}$ on a molar basis (Linsdell et al. 1997). Airway cells generate OSCN from $\mathrm{H}_{2} \mathrm{O}_{2}$ using membranetethered dual oxidases (Duox1 and 2), and $\mathrm{H}_{2} \mathrm{O}_{2}$ is metabolized by secreted lactoperoxidase to oxidize secreted SCN to the OSCN anion. SCN reaches concentrations of $\sim 0.5 \mathrm{~mm}$ in the ASL, which is at least $\sim 30$ times its concentration in the serum. In vitro studies have implicated the Na-dependent iodide cotransporter, which is highly expressed in thyroid gland cells, in the accumulation of SCN across the basolateral membranes of airway cells for subsequent exit through CFTR. Accordingly, in CF, the loss of SCN transport would impair OSCN-dependent bacterial killing and contribute to bacterial colonization and disease pathogenesis.

It is interesting that therapy with hypertonic saline in CF (Elkins et al. 2006), which is thought to improve the hydration of the airway surface, has been reported to produce improvements in ASL levels of both SCN and GSH. Nebulization of hypertonic saline in mice increased ASL SCN and GSH, and these increases were smaller in CFTR knockout animals (Gould et al. 2010). 
R.A. Frizzell and J.W. Hanrahan

\section{FLUID SECRETION LINKED TO SALT TRANSPORT}

\section{Which Transporters Drive Fluid Secretion and Mediate Water Flux?}

Fluid secretion by airway submucosal gland acinar cells is driven by active $\mathrm{Cl}^{-}$transport, whereas $\mathrm{HCO}_{3}^{-}$net flux drives fluid transport across other epithelia, such as pancreatic ducts and regions of the GI tract (e.g., duodenum). The well-studied model human airway cell line Calu-3 does not transport $\mathrm{Cl}^{-}$actively at detectable rates under short-circuit conditions (Devor et al. 1999); nevertheless, recent studies indicate that a small net $\mathrm{Cl}^{-}$flux generates the osmotic driving force for fluid transport by Calu-3 cells under thin film conditions (Shan et al. 2011). This $\mathrm{Cl}^{-}$transport requires basolateral anion exchange, and a similar mechanism may occur in salivary and airway glands and other tissues where a large component of the fluid secretion is insensitive to bumetanide. This $\mathrm{HCO}_{3}^{-}$-dependent $\mathrm{Cl}^{-}$transport contrasts with the duodenum and especially the pancreatic duct, where fluid secretion is driven by $\mathrm{HCO}_{3}^{-}$itself, and as discussed above, the luminal $\mathrm{NaHCO}_{3}$ in the secretions reaches very high concentrations, for example, $140 \mathrm{~mm}$ (Steward et al. 2005). Water follows the net transport of solutes through both paracellular and trans-cellular pathways in secretory epithelia. In human airways, the transcellular pathway consists of apical AQP5 and predominantly basolateral AQP3 and AQP4 water channels (Kreda et al. 2001). Interestingly, the infection of mouse airways with adenovirus leads to reduced expression of AQP1 and AQP3 in endothelial and epithelial cells, respectively, which may contribute to pulmonary edema (Towne et al. 2000).

\section{REGULATION}

Evidence for Local Activation by cAMP/PKA

CFTR is hypothesized to be part of a signaling complex that includes scaffolds, adaptors, and many regulatory enzymes (kinases, phosphatases, cyclases, phosphodiesterases, cAMP ex- porters, etc.). Interactions with these proteins enables CFTR channel regulation to be spatially and temporally restricted (Huang et al. 2001). PKA is localized near CFTR by an A-kinase anchoring protein (AKAP) (Gray et al. 2000), probably ezrin, because it coimmunoprecipitates with CFTR, binds to a regulatory subunit of PKA, and is expressed at the apical membranes of Calu-3 and T84 cells (Sun et al. 2000b). CFTR channels can be activated by adding cAMP to excised membrane patches; therefore, the entire PKA holoenzyme must be tethered (Huang et al. 2000). This was also shown biochemically by coimmunoprecipitation of the catalytic and regulatory subunits of PKA with CFTR (Sun et al. 2000a,b) and by showing that endogenous PKA activity in the immunoprecipitates was sensitive to a peptide that disrupts AKAP interactions. Recent studies have shown that phosphodiesterase type 3A (PDE3A) is linked functionally to CFTR activation and that its inhibition produces a localized increase in cAMP, which also enhances the physical interaction of PDE3A with CFTR and augments CFTR activity (Penmatsa et al. 2010). This interaction depended on the cytoskeleton, and its disruption blocked compartmentalized cAMP signaling. PKC- $\varepsilon$ and Src are also tethered in the putative CFTR complex by a protein called RACK1 (regulator of activated C kinase) (Yarwood et al. 1999; Chang et al. 2001).

\section{Local Activation by cGMP/PKG}

In intestinal epithelium, the cGMP-dependent kinase, type II (French et al. 1995), regulates CFTR activity independent of PKA and in response to luminal peptide hormones, the guanylins, and the diarrhea-producing, heat-stable enterotoxin, as shown by inhibitor and gene knockout studies (Vaandrager et al. 1998). The type II PKG is amino-terminally myristolated (Vaandrager et al. 1996) and is attached through this lipid anchor to the apical membranes of intestinal epithelial cells, where it is in a privileged position to elicit CFTR phosphorylation. Indeed, the kinase and CFTR coimmunoprecipitate. The association of PDE3A with CFTR, noted above, has implications not only for 
cAMP/PKA signaling but also for localized cGMP/PKG signaling. Because type 3A PDE degrades both cAMP and cGMP, increases in cGMP will block its degradation of cAMP and permit PKA-dependent CFTR activation in addition to that produced by the cGMP kinase.

\section{Inactivation of CFTR}

CFTR is deactivated by association with the phosphatases PP2C and PP2A (Zhu et al. 1999; Thelin et al. 2005). The cAMP signal is kept local and transient by the action of phosphodiesterase PDE4D, which interacts with both NHERF1 (see below) and RACK1 (Barnes et al. 2005). In the intestine, cAMP is also regulated locally by MRP4, a cAMP exporter that associates with CFTR (Li et al. 2007a). CFTR activity is downregulated during metabolic stress by the $\alpha 1$ and $\alpha 2$ catalytic subunits of AMP-activated protein kinase (AMPK), which binds to CFTR at its carboxyl terminus (Hallows et al. 2000). AMPK inhibits CFTR by phosphorylating an inhibitory site at position 768 within the $\mathrm{R}$ domain of CFTR. CFTR is also inhibited by binding of the t-SNARE syntaxin 1A, which disrupts the association of the amino terminus with the R domain (Naren et al. 2000). MUNC18 relieves this inhibition by binding to syntaxin $1 \mathrm{~A}$ (Naren and Kirk 2000), although there is evidence that syntaxin $1 \mathrm{~A}$ also inhibits CFTR trafficking to the membrane (Peters et al. 1999). The $\beta$-adrenergic receptor forms a macromolecular complex with CFTR in airway epithelial cells (Naren et al. 2003), and similar results have been obtained in mouse intestine (U Seidler, pers. comm.).

\section{PDZ and WD-Domain Proteins Hold Things Together}

At least two types of scaffold proteins have been identified that may help assemble CFTR regulatory complexes-PDZ domain proteins and WD-domain proteins. PDZ (postsynaptic density 95, Discs large, ZO-1) domain proteins bind to the carboxyl terminus of CFTR and help to stabilize it at the plasma membrane. Mutating threonine or leucine in the ${ }^{1477}$ DTRL motif inhibits PDZ binding and leads to par- tial redistribution of CFTR from the apical to the lateral plasma membrane (Short et al. 1998; Wang et al. 1998). However, removing the carboxyl terminus does not completely eliminate CFTR binding to PDZ domains because of the presence of an internal six-aminoacid binding site upstream in the carboxyl terminus of CFTR (LaRusch 2007). Sodium hydrogen exchange regulatory factor (NHERF1) is one such PDZ-domain protein that binds CFTR. It has two PDZ domains that can both bind CFTR with different affinities (see below). The carboxyl terminus of NHERF1 acts as a switch that enables PDZ2 to bind CFTR when the carboxyl terminus is phosphorylated by PKC or interacts with ezrin (Li et al. 2007b). PDZ2 also binds YAP65, which recruits the Src family tyrosine kinase $\mathrm{p} 62^{\mathrm{c}-\mathrm{yes}}$ to the apical membrane (Mohler et al. 1999), although the functional role of this interaction is not yet known.

A related PDZ-domain protein, NHERF2 (also called E3KARP), is expressed at the apical membrane of epithelia and can be immunoprecipitated with CFTR (Sun et al. 2000), as can CAP70 (NHERF3), a protein with four PDZ domains that was identified by affinity purification using the C-tail of CFTR (Wang et al. 2000). Adding CAP70 increases CFTR channel activity at low concentrations and decreases it at high concentrations, and similar results have been reported with fragments of NHERF1 (Raghuram et al. 2001). Another PDZ-domain protein that forms complexes with CFTR is CAL (CFTR-associated ligand), which has a single PDZ domain and two coiled-coil domains. CAL interacts with CFTR in the trans-Golgi network (TGN) and inhibits its surface expression (Cheng et al. 2010). The PDZ-domain protein Shank2E binds to the carboxyl terminus of CFTR and functions as a negative regulator. It has ankyrin repeats and is concentrated in actin complexes at the apical membrane of epithelial cells (McWilliams et al. 2008), where it may recruit the cyclic nucleotide phosphodiesterase PDE4D (Lee et al. 2008) and phospholipase $C-\beta 3$.

The best studied WD domain protein is RACK1 (receptor for activated C kinase). It has 
a $\beta$-propeller structure and sequence homology with the $\beta$ subunit of heterotrimeric G-proteins, an ancient family of regulatory proteins with repeating units that usually end with TrpAsp (WD). Based mainly on coimmunoprecipitation results, RACK1 can interact with NHERF1 (Liedtke and Wang 2006), PKC-ع (Liedtke et al. 2002), PDE4D, and Src (Chang et al. 2001; Cox et al. 2003).

It has been proposed that positive regulators such as NHERF1 and negative regulators such as CAL and Shank2 compete for CFTR (Kim et al. 2004). The CFTR affinities of NHERF1 $\left(K_{\mathrm{d}}=200\right.$ and $\left.1000 \mathrm{~nm}\right)$ and NHERF2 $\left(K_{\mathrm{d}}=\right.$ 323 and $232 \mathrm{~nm}$ ) are much higher than that of CAL $\left(K_{\mathrm{d}}>600 \mu \mathrm{M}\right)$, which may explain why CFTR normally trafficks toward the plasma membrane rather than to the lysosome (Cushing et al. 2008). Finally, there is evidence for the interaction of CFTR with the actin cytoskeleton (Cantiello 2001), and the amino terminus of CFTR can also associate with the actin cytoskeleton through filamin (Thelin et al. 2007).

\section{Cross Talk between Signaling Pathways}

Although the apparent stimulation of CFTR by Ca-mobilizing agonists and synergistic regulation by signaling pathways has caused confusion, it is now clear that many observations can be explained by localized signaling domains near the plasma membrane and overlap between cAMP and $\mathrm{Ca}$ signaling. For example, ATP-induced Ca release from stores enhances store-operated $\mathrm{Ca}$ entry, and the subsequent local activation of Ca-stimulated adenylyl cyclase 1 or 8 and elevation of cAMP (Martin et al. 2009; Namkung et al. 2010). Even without triggering influx of extracellular $\mathrm{Ca}$, release from stores can elevate cAMP through a store-operated cAMP signaling mechanism in which STIM1 activates adenylyl cyclases (Lefkimmiatis et al. 2009). These pathways also intersect at the level of Ca stores, where cAMP enhances IP3 receptor activation, thereby contributing to synergistic regulation of secretion by these two second messengers (Lee and Foskett 2010).

\section{CF AFFECTS EPITHELIUM-SPECIFIC ANION SECRETORY FUNCTIONS}

The impact of CFTR-mediated anion secretion in different organ systems is often modified or augmented by transporters/channels that lie in parallel with CFTR at the apical membrane, as discussed above. These pathways may either support its secretory function by adding to CFTR-mediated anion secretion or altering secretory composition (see alternate anion pathways, above), or they may oppose or balance net salt and water transport using an oppositely directed transport process, for example, $\mathrm{Na}$ absorption across airway epithelia. Organ-specific functions also arise from modification of the primary secretory product of exocrine gland acini by downstream, ductal transport events to provide a secretory product of volume and composition appropriate to the physiology of that tissue/organ. More detailed treatments of the functions of specific organ systems can be found in other chapters in this collection.

To generalize, CFTR-mediated anion secretion in some organs maintains the volume (and liquidity) of the luminal compartment and its contents, for example, airway, intestines. In the exocrine organs, for example, pancreas and salivary gland, CFTR-dependent anion secretion provides the vehicle for clearing secreted products like macromolecules to another location. It would be argued that anion secretion serves both functions in the surface and submucosal gland epithelia that line the airway. In contrast to these organs, the sweat gland is spared from similar pathologic consequences in CF, presumably because the secretory coil in humans is controlled primarily by CFTR-independent, cholinergic pathways and Ca-dependent channels.

\section{Airway Epithelia}

Anion secretion in the airways contributes to the formation and maintenance of a thin layer of liquid, the airway surface liquid (ASL), which consists of a lower-viscosity periciliary liquid (PCL) layer (referred to as "sol") adjacent to the apical membrane, in which the cilia beat, and a higher-viscosity gel layer where secreted mucins trap inhaled microorganisms 
Physiology of Chloride and Fluid Secretion

and debris. Airway anion secretion is critically important in maintaining the volume and composition of the PCL. Opposing Na absorptive $(\mathrm{ENaC})$ and $\mathrm{Cl}$ secretory (CFTR and CACC) transport processes are important in determining the depth of the PCL on which the efficiency of mucociliary clearance depends (see Fig. 3) (Matsui et al. 1998; Tarran 2004). Anion secretory processes are expressed in the ciliated surface airway epithelium, but a significant volume of liquid (and defense molecules) is generated also by the submucosal glands present in the more proximal airway. In the upper airways, gland secretion may contribute most of the secreted liquid, but adjustments performed by the surface epithelium via localized control mechanisms regulate an optimal PCL depth. It is clear, particularly from studies using primary cultures of upper airway cells, that the surface cells have the capacity to regulate PCL depth in the 6- to $10-\mu \mathrm{m}$ range (Tarran 2004). The factors influencing ASL properties in the lower airways are much less clear.

In CF, the absence or defective function of CFTR at the apical membranes compromises the formation of a sufficient PCL, and ENaCmediated $\mathrm{Na}$ absorption is enhanced. These de- fects result in the near absence of the low-viscosity fluid layer on which effective mucus clearance depends. This leads to the accumulation of mucus and bacteria, particularly Pseudomonas aeruginosa and other opportunistic infections that colonize airway surfaces and obstruct smaller airways and gland ducts caused by the loss of vehicle. This situation is further compromised by the loss of the innate immune substances present in their secretions.

\section{Intestines}

The secretion of salt and water by the small and large intestines is important for maintaining a semiliquid luminal environment that supports enzyme activities, the absorption of nutrients, and for optimal clearance of the luminal contents. The proximal small intestine is primarily involved in salt absorption and bicarbonate secretion, the latter to buffer gastric acid. Here, coupled $\mathrm{Na} / \mathrm{H}$ and $\mathrm{Cl} / \mathrm{HCO} 3$ exchangers account primarily for salt and water handling. In the more distal small intestine, CFTR is expressed primarily in the crypt cells as determined by in situ hybridization, immunofluorescence, and functional measurements,
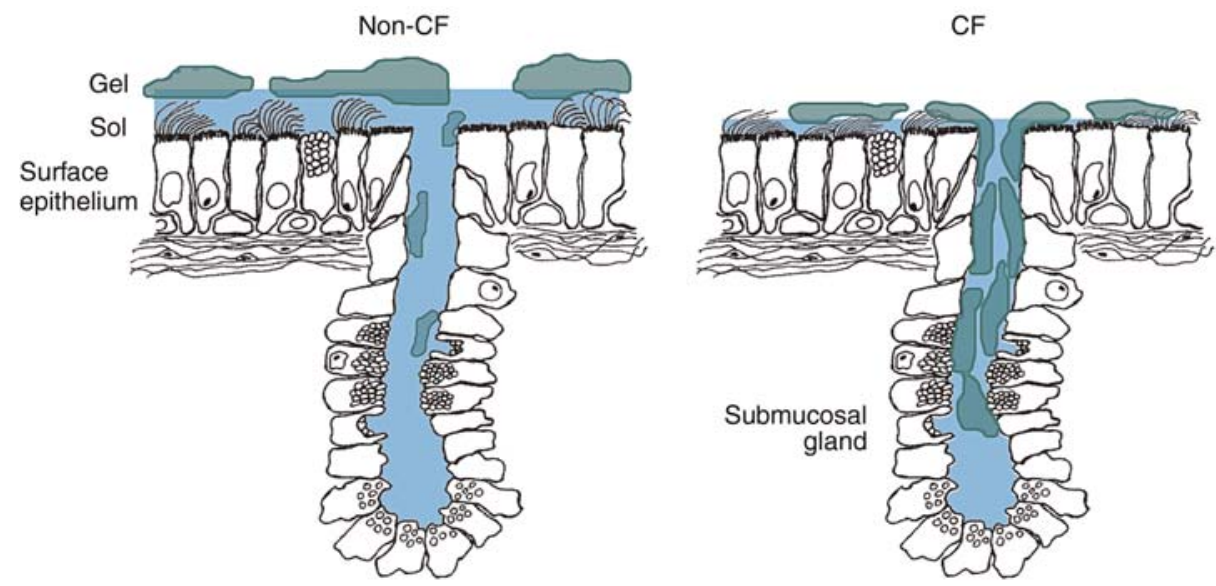

Figure 3. Cartoon illustrating the impact of impaired airway secretion on mucociliary clearance. Contributions to the volume and composition of the airway surface liquid (ASL) emerge from the surface epithelium and submucosal glands. The surface epithelium of non-CF airways adjusts the depth of the periciliary liquid layer (PCL) to a level that enables ciliary beating and effective mucociliary clearance. In CF, the absence of sufficient CFTR function compromises salt and water secretion, PCL regulation, and mucus clearance from the surface epithelium and gland ducts. Mucus accumulation leads to infection, inflammation, and bronchiectasis. 
although high CFTR-expressing cells are evident on the villi (Ameen et al. 1995). In the large intestine, CFTR is localized to the crypt epithelium. The model of Figure 1 applies to CFTRmediated anion secretion in the distal small intestine and colon, and the counterion $\mathrm{Na}$ moves through the paracellular pathway, as shown, in response to the favorable trans-epithelial lumen-negative voltage, as in airway cells.

In CF, insufficient anion secretion may lead to blockage of the intestinal lumen at birth by meconium as an early clinical symptom of the disease. Later in life, patients may experience chronic constipation, reflecting the continued lack of CFTR-mediated secretion. Mice without CFTR or expressing $\Delta$ F508 CFTR exhibit a more severe intestinal phenotype than CF patients, which is confirmed by compromised cAMP/ PKA stimulation of $\mathrm{Cl}$ transport in trans-epithelial measurements in vitro (Clarke et al. 1992; Grubb and Gabriel 1997). On the other side of the coin, CFTR plays a key role in the amplified response observed in secretory diarrheas, such as those elicited by cholera toxin during infection with Vibrio cholerae or by heat-stable enterotoxin during infection with pathogenic Escherichia coli (Chao et al. 1994; Gabriel et al. 1994). Small-molecule blockers of CFTR may prove valuable in treating these conditions (e.g., Thiagarajah et al. 2004), because these toxins are ineffective in CF mice (Grubb and Gabriel 1997).

\section{Pancreas and Salivary Gland}

CFTR is expressed in the duct cells of the exocrine pancreas and salivary glands by in situ hybridization and antibody labeling (Marino et al. 1991; Trezise and Buchwald 1991). Evidence suggests also that CFTR is present in the salivary acini and in the intralobular cells of the pancreas, which extend into the acinar lumen. In these acinar regions, the expression level of CFTR appears to be lower than the corresponding ductal levels. The involvement of CFTR in formation of the primary secretory product by acinar or intralobular cells is supported by the actions of cAMP/PKA-dependent secretogogues, for example, secretin and adrenergic agonists. In the pancreatic duct, CFTR couples functionally to the anion exchangers SLC26A3 and SLC26A6 to generate $\mathrm{NaHCO}_{3}$ secretion for alkalinizing the duodenal lumen (discussed under alternative anion transport, above). Together with the primary acinar secretion, these isotonic secretory products provide the vehicle for the delivery of pancreatic digestive enzymes to the duodenal lumen, and, physiologically, this process is similar for salivary clearance of mucins and enzymes (Zeng et al. 1997).

In CF, most but not all CFTR mutations produce pancreatic insufficiency, making pancreatic function a biomarker for disease severity (Wilschanski and Durie 2007). Patients could be grouped as pancreatic sufficient (PS) or insufficient (PI), based on whether they required replacement enzyme therapy, even before the CF gene was identified. Both PS and PI patients exhibit reduced fluid and anion secretion, with the secretory defect more pronounced in PI. Nevertheless, PS patients are prone to recurrent pancreatitis (see above). Failure of anion secretion results in duct or gland blockage by precipitated macromolecules, and the subsequent leakage of proteolytic enzymes, which destroys the exocrine parenchyma. Damage to the pancreas begins even in utero, when ductal obstruction leads to luminal dilation, atrophy, and fibrosis, and thus, cystic fibrosis of the pancreas. As patients age, pancreatic islets may also be lost with the development of CF-related diabetes.

\section{CONCLUDING THOUGHTS}

The loss of CFTR's ion channel function at the apical membranes of secretory epithelial cells leads to defects that are now conceptually understandable based on modifications of, or additions to, the basic model for secondary active Cl secretion that emerged in the 1970s (Fig. 1). Disease pathology within the affected organ systems depends on the contribution of CFTR function to salt and water secretion, relative to the activity of other pathways. Its impact in different organ systems relates also to the locus of CFTR expression within the tissue and the developmental consequences of deficient CFTR. For example, it is estimated that as little as 
$20 \%$ impairment in $\mathrm{Cl}$ secretion is sufficient to produce obstructive degeneration of the vas deferens (Marcorelles et al. 2011), making its development particularly sensitive to CFTR expression. In the pancreas, $\sim 20 \%$ of normal CFTR function is required for pancreatic-sufficient CF disease. In the sweat gland, a 50\% impairment of CFTR activity is not detectable as a change in sweat $\mathrm{Cl}$, and relatively little CFTR activity produces a significant drop in sweat $\mathrm{Cl}$. A broad variation in CFTR function is found amidst the more than 1700 reported mutations and polymorphisms in CFTR, and these can provide an indication of the relative amount of CFTR function needed for therapeutic benefit. It becomes increasingly clear that the core defect in CF disease is anion transport, making CFTR the prime target for therapeutic development.

\section{ACKNOWLEDGMENTS}

The work of the authors is supported by grants from the NIH-NIDDK and from the Cystic Fibrosis Foundation to R.A.F; and from Cystic Fibrosis Canada and the CIHR to J.W.H. We also thank Natalie Schweninger and Xiaoyan Gong for help with the manuscript.

\section{REFERENCES}

Ameen NA, Ardito T, Kashgarian M, Marino CR. 1995. A unique subset of rat and human intestinal villus cells express the cystic fibrosis transmembrane conductance regulator. Gastroenterology 108: 1016-1023.

Aronson PS. 2010. Role of SLC26A6-mediated Cl-oxalate exchange in renal physiology and pathophysiology. $J$ Nephrol 23(Suppl 16): S158-S164.

Baker JM, Hudson RP, Kanelis V, Choy WY, Thibodeau PH, Thomas PJ, Forman-Kay JD. 2007. CFTR regulatory region interacts with NBD1 predominantly via multiple transient helices. Nat Struct Mol Biol 14: 738-745.

Barnes AP, Livera G, Huang P, Sun C, O’Neal WK, Conti M, Stutts MJ, Milgram SL. 2005. Phosphodiesterase 4D forms a cAMP diffusion barrier at the apical membrane of the airway epithelium. J Biol Chem 280: 7997-8003.

Barrett KE, Keely SJ. 2000. Chloride secretion by the intestinal epithelium: Molecular basis and regulatory aspects. Annu Rev Physiol 62: 535-572.

Bertrand CA, Zhang R, Pilewski JM, Frizzell RA. 2009. SLC26A9 is a constitutively active, CFTR-regulated anion conductance in human bronchial epithelia. J Gen Physiol 133: $421-438$.

Cantiello HF. 2001. Role of actin filament organization in CFTR activation. Pflugers Arch 443 (Suppl 1): S75-S80.
Caputo A, Caci E, Ferrera L, Pedemonte N, Barsanti C, Sondo E, Pfeffer U, Ravazzolo R, Zegarra-Moran O, Galietta LJ. 2008. TMEM16A, a membrane protein associated with calcium-dependent chloride channel activity. Science 322: 590-594.

Chang BY, Chiang M, Cartwright CA. 2001. The interaction of Src and RACK1 is enhanced by activation of protein kinase $\mathrm{C}$ and tyrosine phosphorylation of RACK1. J Biol Chem 276: 20346-20356.

Chao AC, de Sauvage FJ, Dong YJ, Wagner JA, Goeddel DV, Gardner P. 1994. Activation of intestinal CFTR Cl${ }^{-}$channel by heat-stable enterotoxin and guanylin via cAMPdependent protein kinase. EMBO J 13: 1065-1072.

Chen JH, Stoltz DA, Karp PH, Ernst SE, Pezzulo AA, Moninger TO, Rector MV, Reznikov LR, Launspach JL, Chaloner K, et al. 2010. Loss of anion transport without increased sodium absorption characterizes newborn porcine cystic fibrosis airway epithelia. Cell 143: 911923.

Cheng J, Moyer BD, Milewski M, Loffing J, Ikeda M, Mickle JE, Cutting GR, Li M, Stanton BA, Guggino WB. 2002. A Golgi-associated PDZ domain protein modulates cystic fibrosis transmembrane regulator plasma membrane expression. J Biol Chem 227: 3520-3529.

Cheng J, Cebotaru V, Cebotaru L, Guggino WB. 2010. Syntaxin 6 and CAL mediate the degradation of the cystic fibrosis transmembrane conductance regulator. Mol Biol Cell 21: 1178-1187.

Clarke LL, Grubb BR, Gabriel SE, Smithies O, Koller BH, Boucher RC. 1992. Defective epithelial chloride transport in a gene-targeted mouse model of cystic fibrosis. Science 257: $1125-1128$

Clayburgh DR, Barrett TA, Tang Y, Meddings JB, Van Eldik LJ, Watterson DM, Clarke LL, Mrsny RJ, Turner JR. 2005. Epithelial myosin light chain kinase-dependent barrier dysfunction mediates $\mathrm{T}$ cell activation-induced diarrhea in vivo. J Clin Invest 115: 2702-2715.

Conner GE, Wijkstrom-Frei C, Randell SH, Fernandez VE, Salathe M. 2007. The lactoperoxidase system links anion transport to host defense in cystic fibrosis. FEBS Lett 581: $271-278$.

Cox EA, Bennin D, Doan AT, O’Toole T, Huttenlocher A. 2003. RACK1 regulates integrin-mediated adhesion, protrusion, and chemotactic cell migration via its Src binding site. Mol Biol Cell 14: 658-669.

Cushing PR, Fellows A, Villone D, Boisguérin P, Madden DR. 2008. The relative binding affinities of PDZ partners for CFTR: A biochemical basis for efficient endocytic recycling. Biochemistry 47: 10084-10098.

Cuthbert AW, Supuran CT, MacVinish LJ. 2003. Bicarbonate-dependent chloride secretion in Calu-3 epithelia in response to 7,8-benzoquinoline. J Physiol 551: 79-92.

Day BJ, van Heeckeren AM, Min E, Velsor LW. 2004. Role for cystic fibrosis transmembrane conductance regulator protein in a glutathione response to bronchopulmonary pseudomonas infection. Infect Immun 72: 2045-2051.

Devor DC, Frizzell RA. 1998. Modulation of $\mathrm{K}^{+}$channels by arachidonic acid in T84 cells. I. Inhibition of the $\mathrm{Ca}^{2+}$. dependent $\mathrm{K}^{+}$channel. Am J Physiol 274: C138-C148.

Devor DC, Singh AK, Lambert LC, DeLuca A, Frizzell RA, Bridges RJ. 1999. Bicarbonate and chloride secretion in 
R.A. Frizzell and J.W. Hanrahan

Calu-3 human airway epithelial cells. J Gen Physiol 113: $743-760$.

Dorwart MR, Shcheynikov N, Baker JM, Forman-Kay JD, Muallem S, Thomas PJ. 2008a. Congenital chloride-losing diarrhea causing mutations in the STAS domain result in misfolding and mistrafficking of SLC26A3. J Biol Chem 283: 8711-8722.

Dorwart MR, Shcheynikov N, Yang D, Muallem S. 2008b. The solute carrier 26 family of proteins in epithelial ion transport. Physiology (Bethesda) 23: 104-114.

Eisenman G. 1962. Cation selective glass electrodes and their mode of operation. Biophys J 2: 259-323.

Elkins MR, Robinson M, Rose BR, Harbour C, Moriarty CP, Marks GB, Belousova EG, Xuan W, Bye PT. 2006. A controlled trial of long-term inhaled hypertonic saline in patients with cystic fibrosis. N Engl J Med 354: 229-240.

Evans MG, Marty A. 1986. Calcium-dependent chloride currents in isolated cells from rat lacrimal glands. JPhysio 378: $437-460$.

Ferrera L, Caputo A, Galietta LJ. 2010. TMEM16A protein: A new identity for $\mathrm{Ca}^{2+}$-dependent $\mathrm{Cl}^{-}$channels. Physiology (Bethesda) 25: 357-363.

French PJ, Bijman J, Edixhoven M, Vaandrager AB, Scholte BJ, Lohmann SM, Nairn AC, de Jonge HR. 1995. Isotypespecific activation of cystic fibrosis transmembrane conductance regulator-chloride channels by cGMP-depen dent protein kinase II. J Biol Chem 270: 26626-26631.

Frizzell RA, Field M, Schultz SG. 1979. Sodium-coupled chloride transport by epithelial tissues. Am J Physiol 236: F1-F8.

Frömter E, Diamond J. 1972. Route of passive ion permeation in epithelia. Nat New Biol 235: 9-13.

Gabriel SE, Brigman KN, Koller BH, Boucher RC, Stutts MJ. 1994. Cystic fibrosis heterozygote resistance to cholera toxin in the cystic fibrosis mouse model. Science 266: 107-109.

Gawenis LR, Ledoussal C, Judd LM, Prasad V, Alper SL, Stuart-Tilley A, Woo AL, Grisham C, Sanford LP, Doetschman T, et al. 2004. Mice with a targeted disruption of the $\mathrm{AE}^{\mathrm{Cl}^{-}} / \mathrm{HCO}_{3}^{-}$exchanger are achlorhydric. J Biol Chem 279: 30531-30539.

Gawenis LR, Bradford EM, Alper SL, Prasad V, Schull GE. 2010. $\mathrm{AE} \mathrm{Cl}^{-} / \mathrm{HCO}_{3}^{-}$exchanger is required for normal cAMP-stimulated anion secretion in murine proximal colon. Am J Physiol Gastrointest Liver Physiol 298: G493-G503.

Gerlach U, Brendel J, Lang HJ, Paulus EF, Weidmann K, Bruggemann A, Busch AE, Suessbrich H, Bleich M, Greger R. 2001. Synthesis and activity of novel and selective $\mathrm{I}_{\mathrm{Ks}^{-}}$-channel blockers. J Med Chem 44: 3831-3837.

Gibson A, Lewis AP, Affleck K, Aitken AJ, Meldrum E, Thompson N. 2005. hCLCA1 and mCLCL3 are secreted non-integral membrane proteins and therefore are not ion channels. J Biol Chem 280: 27205-27212.

Gould NS, Gauthier S, Kariya CT, Min E, Huang J, Brian DJ. 2010. Hypertonic saline increases lung epithelial lining fluid glutathione and thiocyanate: Two protective CFTRdependent thiols against oxidative injury. Respir Res 11: 119.

Gray PC, Scott JD, Catterall WA. 2000. Regulation of ion channels by cAMP-dependent protein kinase and A-ki- nase anchoring proteins. Curr Opin Neurobiol 8: 330334.

Grubb BR, Gabriel SE. 1997. Intestinal physiology and pathology in gene-targeted mouse models of cystic fibrosis. Am J Physiol 273: G258-G266.

Haddad JJ. 2002. Redox regulation of pro-inflammatory cytokines and IкB- $\alpha /$ NF- $\kappa$ B nuclear translocation and activation. Biochem Biophys Res Commun 296: 847-856.

Hallows KR, Raghuram V, Kemp BE, Witters LA, Foskett JK 2000. Inhibition of cystic fibrosis transmembrane conductance regulator by novel interaction with the metabolic sensor AMP-activated protein kinase. J Clin Invest 105: $1711-1721$.

Hamann M, Gibson A, Davies N, Jowett A, Walhin JP, Partington L, Affleck K, Trezise D, Main M. 2009. Human ClCal modulates anionic conduction of calcium-dependent chloride currents. J Physiol 587: 2255-2274.

Hartzell HC, Qu Z, Yu K, Xiao Q, Chien LT. 2008. Molecular physiology of bestrophins:multifunctional membrane proteins linked to Best disease and other retinopathies. Physiol Rev 88: 639-672.

Heitzmann D, Warth R. 2008. Physiology and pathophysiology of potassium channels in gastrointestinal epithelia. Physiol Rev 88: 1119-1182.

Hoglund P, Haila S, Socha J, Tomaszewski L, Saarialho-Kere U, Karjalainen-Lindsberg ML, Airola K, Holmberg C, de la Chapelle A, Kere J. 1996. Mutations of the Down-regulated in adenoma (DRA) gene cause congenital chloride diarrhoea. Nat Genet 14: 316-319.

Huang P, Trotter K, Boucher RC, Milgram SL, Stutts MJ. 2000. PKA holoenzyme is functionally coupled to CFTR by AKAPs. Am J Physiol Cell Physiol 278: C417-C422.

Huang P, Lazarowski ER, Tarran R, Milgram SL, Boucher RC, Stutts MJ. 2001. Compartmentalized autocrine signaling to cystic fibrosis transmembrane conductance regulator at the apical membrane of airway epithelial cells. Proc Natl Acad Sci 98: 14120-14125.

Huang J, Shan J, Alper SL, Hanrahan JW. 2011. Secretion by the human airway epithelial cell line Calu-3 depends on basolateral chloride loading by AE2. Proc Physiol Soc 23: 160.

Ishiguro H, Namkung W, Yamamoto A, Wang Z, Worrell RT, Xu J, Lee MG, Soleimani M. 2007. Effect of Slc26a6 deletion on apical $\mathrm{Cl}^{-} / \mathrm{HCO}_{3}^{-}$exchanger activity and cAMPstimulated bicarbonate secretion in pancreatic duct. Am J Physiol Gastrointest Liver Physiol 292: G447-G455.

Joiner WJ, Basavappa S, Vidyasagar S, Nehrke K, Krishnan S, Binder HJ, Boupaep EL, Rajendran VM. 2003. Active $\mathrm{K}^{+}$ secretion through multiple $\mathrm{K}_{\mathrm{Ca}}$-type channels and regulation by $\mathrm{IK}_{\mathrm{Ca}}$ channels in rat proximal colon. Am J Physiol Gastrointest Liver Physiol 285: G185-G196.

Kanelis V, Hudson RP, Thibodeau PH, Thomas PJ, FormanKay JD. 2010. NMR evidence for differential phosphorylation-dependent interactions in WT and $\Delta$ F508 CFTR. EMBO J 29: 263-277.

Kim JY, Han W, Namkung W, Lee JH, Kim KH, Shin H, Kim E, Lee MG. 2004. Inhibitory regulation of cystic fibrosis transmembrane conductance regulator anion-transporting activities by Shank2. J Biol Chem 279: 10389-10396. 
Kim KH, Shcheynikov N, Wang Y, Muallem S. 2005. SLC26A7 is a $\mathrm{Cl}^{-}$channel regulated by intracellular pH. J Biol Chem 280: 6463-6470.

Kimberg DV, Field M, Johnson J, Henderson A, Gershon E. 1971. Stimulation of intestinal mucosal adenyl cyclase by cholera enterotoxin and prostaglandins. J Clin Invest 50: $1218-1230$.

Ko SB, Zeng W, Dorwart MR, Luo X, Kim KH, Millen L, Goto H, Naruse S, Soyombo A, Thomas PJ, et al. 2004. Gating of CFTR by the STAS domain of SLC26 transporters. Nat Cell Biol 6: 343-350.

Kreda SM, Gynn MC, Fenstermacher DA, Boucher RC, Gabriel SE. 2001. Expression and localization of epithelial aquaporins in the adult human lung. Am J Respir Cell Mol Biol 24: 224-234.

Krouse ME, Talbott JF, Lee MM, Joo NS, Wine JJ. 2004. Acid and base secretion in the Calu-3 model of human serous cells. Am J Physiol Lung Cell Mol Physiol 287: L1274L1283.

Kunzelmann K, Hubner M, Schreiber R, Levy-Holzman R, Garty H, Bleich M, Warth R, Slavik M, von Hahn T, Greger R. 2001. Cloning and function of the rat colonic epithelial $\mathrm{K}^{+}$channel KVLQT1. J Membr Biol 179: 155-164.

Larsen EH. 2002. Hans H. Ussing-Scientific work: Contemporary significance and perspectives. Biochim Biophys Acta 1566: 2-15.

LaRusch JA. 2007. "A novel internal binding motif in the CFTR C-terminus enhances EBP50 multimerization and facilitates endocytic recycling." $\mathrm{PhD}$ thesis, The Johns Hopkins University, Baltimore, MD.

Lee RJ, Foskett JK. 2010. cAMP-activated $\mathrm{Ca}^{2+}$ signalling is required for CFTR-mediated serous cell fluid secretion in porcine and human airways. J Clin Invest 120: $3137-$ 3148.

Lee JH, Richter W, Namkung W, Kim KH, Kim E, Conti M, Lee MG. 2008. Dynamic regulation of cystic fibrosis transmembrane conductance regulator by competitive interactions of molecular adaptors. J Biol Chem 282: 10414-10422.

Lefkimmiatis K, Srikanthan M, Maiellaro I, Moyer MP, Curci S, Hofer AM. 2009. Store-operated cyclic AMP signalling mediated by STIM1. Nat Cell Biol 11: 433-442.

Li C, Krishnamurthy PC, Penmatsa H, Marrs KL, Wang XQ, Zaccolo M, Jalink K, Li M, Nelson DJ, Schuetz JD, et al. 2007a. Spatiotemporal coupling of cAMP transporter to CFTR chloride channel function in the gut epithelia. Cell 131: 940-951.

Li J, Poulikakos PI, Dai Z, Testa JR, Callaway DJE, Bu Z. 2007b. Protein kinase $C$ phosphorylation disrupts $\mathrm{Na}^{+} / \mathrm{H}^{+}$exchanger regulatory factor 1 autoinhibition and promotes cystic fibrosis transmembrane conductance regulator macromolecular assembly. J Biol Chem 282: 27086-27099.

Liao T, Wang L, Halm ST, Lu L, Fyffe RE, Halm DR. 2005. $\mathrm{K}+$ channel KVLQT1 located in the basolateral membrane of distal colonic epithelium is not essential for activating $\mathrm{Cl}^{-}$secretion. Am J Physiol Cell Physiol 289: C564-C575.

Liedtke CM, Wang X. 2006. The N-terminus of the WD5 repeat of human RACK1 binds to airway epithelial NHERF1. Biochemistry 45: 10270-10277.
Liedtke CM, Yun CHC, Kyle N, Wang D. 2002. PKC- $\varepsilon$ dependent regulation of CFTR involves binding to RACK1, a receptor for activated $\mathrm{C}$ kinase, and RACK1 binding to NHERF1. J Biol Chem 277: 22925-22933.

Linsdell P, Tabcharani JA, Rommens JM, Hou YX, Chang XB, Tsui LC, Riordan JR, Hanrahan JW. 1997. Permeability of wild-type and mutant cystic fibrosis transmembrane conductance regulator chloride channels to polyatomic anions. J Gen Physiol 110: 355-364.

Loffing J, Moyer BD, Reynolds D, Shmukler BE, Alper SL, Stanton BA. 2000. Functional and molecular characterization of an anion exchanger in airway serous epithelial cells. Am J Physiol Cell Physiol 279: C1016-C1023.

Lundberg A. 1957. Secretory potentials in the sublingual gland of the cat. Acta Physiol Scand 40: 21-34.

Marcorelles P, Gillet D, Friocourt G, Ledé F, Samaison L, Huguen G, Ferec C. 2011. Cystic fibrosis transmembrane conductance regulator protein expression in the male excretory duct system during development. Hum Pathol 43: 390-397.

Marino CR, Matovcik LM, Gorelick FS, Cohn JA. 1991. Localization of the cystic fibrosis transmembrane conductance regulator in pancreas. J Clin Invest 88: 712-716.

Martin AC, Willoughby D, Ciruela A, Ayling LJ, Pagano M, Wachten S, Tengholm A, Cooper DM. 2009. Capacitative $\mathrm{Ca}^{2+}$ entry via Orail and stromal interacting molecule 1 (STIM1) regulates adenylyl cyclase type 8 . Mol Pharmacol 75: $830-842$.

Marty A, Tan YP, Trautmann A. 1984. Three types of calcium-dependent channel in rat lacrimal glands. J Physiol 357: 293-325.

Matsui H, Randell SH, Peretti SW, Davis CW, Boucher RC. 1998. Coordinated clearance of periciliary liquid and mucus from airway surfaces. J Clin Invest 102: 11251131.

McCormick JA, Ellison DH. 2011. The WNKs: Atypical protein kinases with pleiotropic actions. Physiol Rev 91: 177-219.

McWilliams RR, Gidey E, Fouassier L, Weed SA, Doctor RB. 2008. Characterization of an ankyrin repeat-containing Shank2 isoform (Shank2E) in liver epithelial cells. Biochem J 380: 181-191.

Mercier-Zuber A, O'Shaughnessy KM. 2011. Role of SPAK and OSR1 signalling in the regulation of $\mathrm{NaCl}$ cotransporters. Curr Opin Nephrol Hypertens 20: 534-540.

Mohler PJ, Kreda SM, Boucher RC, Sudol M, Stutts MJ, Milgram SL. 1999. Yes-associated protein 65 localizes p $62^{\mathrm{c}-\text { Yes }}$ to the apical compartment of airway epithelia by association with EBP50. J Cell Biol 147: 879-890.

Mount DB, Romero MF. 2004. The SLC26 gene family of multifunctional anion exchangers. Pflugers Arch 447: $710-721$.

Namkung W, Song Y, Mills AD, Padmawar P, Finkbeiner WE, Verkman AS. 2009. In situ measurement of airway surface liquid $[\mathrm{K}+]$ using a ratioable $\mathrm{K}+$-selective fluorescent dye. J Biol Chem 284: 15916-15926.

Namkung W, Finkbeiner WE, Verkman AS. 2010. CFTRadenylyl cyclase 1 association responsible for UTP activation of CFTR in well-differentiated primary human bronchial cell cultures. Mol Biol Cell 21: 2639-2648. 
R.A. Frizzell and J.W. Hanrahan

Namkung W, Phuan P-W, Verkman AS. 2011. TMEM16A inhibitors reveal TMEM16A as a minor component of calcium-activated chloride channel conductance in airway and intestinal epithelial cells. J Biol Chem 286: 2365 2374.

Nanda Kumar NS, Sing SK, Rajendran VM. 2010. Mucosal potassium efflux mediated via Kcnn 4 channels provides the driving force for electrogenic anion secretion in colon. Am J Physiol Gastrointest Liver Physiol 299: G707G714.

Naren AP, Kirk KL. 2000. CFTR chloride channels: Binding partners and regulatory networks. News Physiol Sci 15: $57-61$.

Naren AP, Di A, Cormet-Boyaka E, Boyaka PN, McGhee JR, Zhou W, Akagawa K, Fujiwara T, Thome U, Engelhardt JF, et al. 2000. Syntaxin 1A is expressed in airway epithelial cells, where it modulates $\mathrm{CFTR} \mathrm{Cl}^{-}$currents. J Clin Invest 105: $377-386$

Naren AP, Cobb B, Li C, Roy K, Nelson D, Heda GD, Liao J, Kirk KL, Sorscher EJ, Hanrahan JW, et al. 2003. A macromolecular complex of $\beta_{2}$ adrenergic receptor, CFTR, and ezrin/radixin/moesin-binding phosphoprotein 50 is regulated by PKA. Proc Natl Acad Sci 100: 342-346.

Novak I, Young JA. 1986. Two independent anion transport systems in rabbit mandibular salivary glands. Pflügers Arch 407: 649-656.

Ousingsawat J, Martins JR, Schreiber R, Rock JR, Harfe BD, Kunzelmann K. 2009. Loss of TMEM16A causes a defect in epithelial $\mathrm{Ca}^{2+}$-dependent chloride transport. J Biol Chem 284: 28698-28703.

Penmatsa H, Zhang W, Yarlagadda S, Li C, Conoley VG, Yue J, Bahouth SW, Buddington RK, Zhang G, Nelson DJ. 2010. Compartmentalized cyclic adenosine $3^{\prime}, 5^{\prime}$-monophosphate at the plasma membrane clusters PDE3A and cystic fibrosis transmembrane conductance regulator into microdomains. Mol Biol Cell 21: 1097-1110.

Peters KW, Qi J, Watkins SC, Frizzell RA. 1999. Syntaxin 1A inhibits regulated CFTR trafficking in Xenopus oocytes. Am J Physiol Cell Physiol 277: C174-C180.

Petrovic S, Ma L, Wang Z, Soleimani M. 2003. Identification of an apical $\mathrm{Cl}^{-} / \mathrm{HCO}_{3}^{-}$exchanger in rat kidney proximal tubule. Am J Physiol Cell Physiol 285: C608-C617.

Petrovic S, Barone S, Xu J, Conforti L, Ma L, Kujala M, Kere J, Soleimani M. 2004. SLC26A7: A basolateral $\mathrm{Cl}^{-}$, $\mathrm{HCO}_{3}^{-}$exchanger specific to intercalated cells of the outer medullary collecting duct. Am J Physiol Renal Physiol 286: F161-F169.

Pirani D, Evans LA, Cook DI, Young JA. 1987. Intracellular $\mathrm{pH}$ in the rat mandibular salivary gland: The role of $\mathrm{Na}^{-} \mathrm{H}$ and $\mathrm{Cl}^{-} \mathrm{HCO}_{3}$ antiports in secretion. Pflugers Arch 408: 178-184.

Raghuram V, Mak D-OD, Foskett JK. 2001. Regulation of cystic fibrosis transmembrane conductance regulator single-channel gating by bivalent PDZ-domain-mediated interaction. Proc Natl Acad Sci 98: 1300-1305.

Rahman I, MacNee W. 1998. Role of transcription factors in inflammatory lung diseases. Thorax 53: 601-612.

Richardson C, Rafiqi FH, Karlsson HK, Moleleki N, Vandewalle A, Campbell DG, Morrice NA, Alessi DR. 2008. Activation of the thiazide-sensitive $\mathrm{Na}+-\mathrm{Cl}^{-}$cotransporter by the WNK-regulated kinases SPAK and OSR1. J Cell Sci 121: 675-684.
Riordan JR, Rommens JM, Kerem B, Alon N, Rozmahel R, Grzelczak Z, Zielenski J, Lok S, Plavsic N, Chou JL, et al. 1989. Identification of the cystic fibrosis gene: Cloning and characterization of complementary DNA. Science 245: $1066-1073$.

Rock JR, O'Neal WK, Gabriel SE, Randell SH, Harfe BD, Boucher RC, Grubb BR. 2009. Transmembrane protein 16A (TMEM16A) is a $\mathrm{Ca}^{2+}$-regulated $\mathrm{Cl}^{-}$secretory channel in mouse airways. J Biol Chem 284: 1487514880.

Romanenko VG, Catalán MA, Brown DA, Putzier I, Hartzell $\mathrm{HC}$, Marmorstein AD, Gonzalez-Begne M, Rock JR, Harfe BD, Melvin JE. 2010. Tmem16A encodes the $\mathrm{Ca}^{2+}$-activated $\mathrm{Cl}^{-}$channel in mouse submandibular salivary gland acinar cells. J Biol Chem 285: 1299013001.

Rottner M, Freyssinet JM, Martinez MC. 2009. Mechanisms of the noxious inflammatory cycle in cystic fibrosis. Respir Res 10: 23.

Schroeder BC, Cheng T, Jan YN, Jan LY. 2008. Expression cloning of TMEM16A as a calcium-activated chloride channel subunit. Cell 134: 1019-1029.

Schweinfest CW, Spyropoulos DD, Henderson KW, Kim JH, Chapman JM, Barone S, Worrell RT, Wang Z, Soleimani M. 2006. slc26a3 (dra)-deficient mice display chloridelosing diarrhea, enhanced colonic proliferation, and distinct up-regulation of ion transporters in the colon. J Biol Chem 281: 37962-37971.

Seidler U, Rottinghaus I, Hillesheim J, Chen M, Riederer B, Krabbenhoft A, Engelhardt R, Wiemann M, Wang Z, Barone S, et al. 2008. Sodium and chloride absorptive defects in the small intestine in Slc26a6 null mice. Pflugers Arch 455: 757-766.

Shan J, Huang J, Liao J, Robert R, Hanrahan JW. 2011. Anion secretion by a model epithelium: More lessons from Calu-3. Acta Physiol 202: 523-531.

Shcheynikov N, Yang D, Wang Y, Zeng W, Karniski LP, So I, Wall SM, Muallem S. 2008. The Slc26a4 transporter functions as an electroneutral $\mathrm{Cl}^{-} / \mathrm{I}^{-} / \mathrm{HCO}_{3}^{-}$exchanger: Role of Slc26a4 and Slc26a6 in $\mathrm{I}^{-}$and $\mathrm{HCO}_{3}^{-}$secretion and in regulation of CFTR in the parotid duct. J Physiol 586: $3813-3824$.

Short DB, Trotter KW, Reczek D, Kreda SM, Bretscher A, Boucher RC, Stutts MJ, Milgram SL. 1998. An apical PDZ protein anchors the cystic fibrosis transmembrane conductance regulator to the cytoskeleton. J Biol Chem 273: 19797-19801.

Skou JC. 1998. Nobel Lecture. The identification of the sodium pump. Biosci Rep 18: 155-169.

Smith PL, Frizzell RA. 1984. Chloride secretion by canine tracheal epithelium: IV. Basolateral membrane K permeability parallels secretion rate. J Membr Biol 77: 187-199.

Steward MC, Ishiguro H, Case RM. 2005. Mechanisms of bicarbonate secretion in the pancreatic duct. Annu Rev Physiol 67: 377-409.

Stutts MJ, Knowles MR, Gatzy JT, Boucher RC. 1986. Oxygen consumption and ouabain binding sites in cystic fibrosis nasal epithelium. Pediatr Res 20: 1316-1320.

Sun F, Hug MJ, Lewarchik CM, Yun CH, Bradbury NA, Frizzell RA. 2000a. E3KARP mediates the association of ezrin and protein kinase A with the cystic fibrosis 
transmembrane conductance regulator in airway cells. $J$ Biol Chem 275: 29539-29546.

Sun F, Hug MJ, Bradbury NA, Frizzell RA. 2000b. Protein kinase A associates with cystic fibrosis transmembrane conductance regulator via an interaction with ezrin. $J$ Biol Chem 275: 14360-14366.

Suzuki M, Mizuno A. 2004. A novel human $\mathrm{Cl}^{-}$channel family related to Drosophila flightless locus. J Biol Chem 279: 22461-22468.

Tarran R. 2004. Regulation of airway surface liquid volume and mucus transport by active ion transport. Proc Am Thorac Soc 1: 42-46.

Tessier GJ, Traynor TR, Kannan MS, O’Grady SM. 1990. Mechanisms of sodium and chloride transport across equine tracheal epithelium. Am J Physiol Lung Cell Mol Physiol 259: L459-L467.

Thelin WR, Kesimer M, Tarran R, Kreda SM, Grubb BR, Sheehan JK, Stutts MJ, Milgram SL. 2005. The cystic fibrosis transmembrane conductance regulator is regulated by a direct interaction with the protein phosphatase 2A. J Biol Chem 280: 41512-41520.

Thelin WR, Chen Y, Gentzsch M, Kreda SM, Sallee JL, Scarlett CO, Borchers CH, Jacobson K, Stutts MJ, Milgram SL. 2007. Direct interaction with filamins modulates the stability and plasma membrane expression of CFTR. $J$ Clin Invest 117: 364-374.

Thiagarajah JR, Broadbent T, Hsieh E, Verkman AS. 2004. Prevention of toxin-induced intestinal ion and fluid secretion by a small-molecule CFTR inhibitor. Gastroenterology 126: 511-519.

Towne JE, Harrod KS, Krane CM, Menon AG. 2000. Decreased expression of aquaporin (AQP) 1 and AQP5 in mouse lung after acute viral infection. Am J Respir Cell Mol Biol 22: 34-44.

Trezise AE, Buchwald M. 1991. In vivo cell-specific expression of the cystic fibrosis transmembrane conductance regulator. Nature 353: 434-437.

Vaandrager AB, Ehlert EM, Jarchau T, Lohmann SM, de Jonge HR. 1996. N-terminal myristoylation is required for membrane localization of cGMP-dependent protein kinase type II. J Biol Chem 271: 7025-7029.

Vaandrager AB, Smolenski A, Tilly BC, Houtsmuller AB, Ehlert EM, Bot AG, Edixhoven M, Boomaars WE, Lohmann SM, de Jonge HR. 1998. Membrane targeting of cGMP-dependent protein kinase is required for cystic fibrosis transmembrane conductance regulator $\mathrm{Cl}$ - channel activation. Proc Natl Acad Sci 95: 1466-1471.

Wang S, Raab RW, Schatz PJ, Guggino WB, Li M. 1998. Peptide binding consensus of the NHE-RF-PDZ1 do- main matches the C-terminal sequence of cystic fibrosis transmembrane conductance regulator (CFTR). FEBS Lett 427: 103-108.

Wang S, Yue H, Derin RB, Guggino WB, Li M. 2000. Accessory protein facilitated CFTR-CFTR interaction, a molecular mechanism to potentiate the chloride channel activity. Cell 103: 169-179.

Wang Y, Soyombo AA, Shcheynikov N, Zeng W, Dorwart M, Marino CR, Thomas PJ, Muallem S. 2006. Slc26a6 regulates CFTR activity in vivo to determine pancreatic duct $\mathrm{HCO}_{3}^{-}$secretion: Relevance to cystic fibrosis. EMBO J 25: 5049-5057.

Welsh MJ, McCann JD. 1985. Intracellular calcium regulates basolateral potassium channels in a chloride-secreting epithelium. Proc Natl Acad Sci 82: 8823-8826.

Welsh MJ, Smith PL, Frizzell RA. 1983. Chloride secretion by canine tracheal epithelium: III. Membrane resistances and electromotive forces. J Membr Biol 71: 209-218.

Willumsen NJ, Davis CW, Boucher RC. 1989. Intracellular $\mathrm{Cl}^{-}$activity and cellular $\mathrm{Cl}^{-}$pathways in cultured human airway epithelium. Am J Physiol 256: C1033-C1044.

Wilschanski M, Durie PR. 2007. Patterns of GI disease in adulthood associated with mutations in the CFTR gene. Gut 56: 1153-1163.

Wright EM, Diamond JM. 1977. Anion selectivity in biological systems. Physiol Rev 57: 109-157.

Xu J, Song P, Miller ML, Borgese F, Barone S, Riederer B, Wang Z, Alper SL, Forte JG, Shull GE, et al. 2008. Deletion of the chloride transporter Slc26a9 causes loss of tubulovesicles in parietal cells and impairs acid secretion in the stomach. Proc Natl Acad Sci 105: 17955-17960.

Yang YD, Cho H, Koo JY, Tak MH, Cho Y, Shim W-S, Park SP, Lee J, Lee B, Kim B-M, et al. 2008. TMEM16A confers receptor-activated calcium-dependent chloride conductance. Nature 455: 1210-1215.

Yarwood SJ, Steele MR, Scotland G, Houslay MD, Bolger GB. 1999. The RACK1 signaling scaffold protein selectively interacts with the cAMP-specific phosphodiesterase PDE4D5 isoform. J Biol Chem 274: 1490914917.

Zeng W, Lee MG, Yan M, Diaz J, Benjamin I, Marino CR, Kopito R, Freedman S, Cotton C, Muallem S, et al. 1997. Immuno and functional characterization of CFTR in submandibular and pancreatic acinar and duct cells. Am J Physiol 273: C442-C455.

Zhu T, Dahan D, Evaglelidis A, Zheng S-X, Luo J, Hanrahan JW. 1999. Association of cystic fibrosis transmembrane conductance regulator and protein phosphatase 2C.J Biol Chem 274: 29102-29107. 


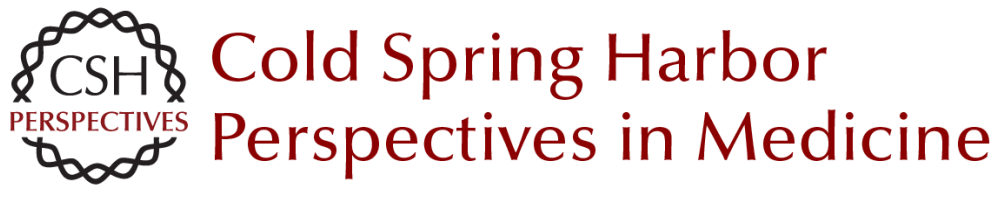

\section{Physiology of Epithelial Chloride and Fluid Secretion}

Raymond A. Frizzell and John W. Hanrahan

Cold Spring Harb Perspect Med 2012; doi: 10.1101/cshperspect.a009563

Subject Collection Cystic Fibrosis

Antibiotic and Anti-Inflammatory Therapies for

Cystic Fibrosis

James F. Chmiel, Michael W. Konstan and J. Stuart Elborn

Structure and Function of the Mucus Clearance System of the Lung

Brenda M. Button and Brian Button

New Pulmonary Therapies Directed at Targets

Other than CFTR

Scott H. Donaldson and Luis Galietta

The Cystic Fibrosis Airway Microbiome

Susan V. Lynch and Kenneth D. Bruce

\section{Cystic Fibrosis Transmembrane Conductance \\ Regulator (ABCC7) Structure \\ John F. Hunt, Chi Wang and Robert C. Ford}

Status of Fluid and Electrolyte Absorption in

Cystic Fibrosis

M.M. Reddy and M. Jackson Stutts

The Influence of Genetics on Cystic Fibrosis

Phenotypes

Michael R. Knowles and Mitchell Drumm

Perspectives on Mucus Properties and Formation

--Lessons from the Biochemical World

Daniel Ambort, Malin E.V. Johansson, Jenny K.

Gustafsson, et al.
The Cystic Fibrosis Intestine

Robert C. De Lisle and Drucy Borowitz

Cystic Fibrosis Transmembrane Regulator

Correctors and Potentiators

Steven M. Rowe and Alan S. Verkman

The Cystic Fibrosis of Exocrine Pancreas

Michael Wilschanski and Ivana Novak

Dynamics Intrinsic to Cystic Fibrosis Transmembrane Conductance Regulator Function and Stability

P. Andrew Chong, Pradeep Kota, Nikolay V.

Dokholyan, et al.

The Cystic Fibrosis Gene: A Molecular Genetic

Perspective

Lap-Chee Tsui and Ruslan Dorfman

The CFTR Ion Channel: Gating, Regulation, and

Anion Permeation

Tzyh-Chang Hwang and Kevin L. Kirk

Assessing the Disease-Liability of Mutations in CFTR

Claude Ferec and Garry R. Cutting

Supramolecular Dynamics of Mucus Pedro Verdugo

For additional articles in this collection, see http://perspectivesinmedicine.cshlp.org/cgi/collection/ 